http://dx.doi.org/10.11646/zootaxa.3736.5.6

http://zoobank.org/urn:lsid:zoobank.org:pub:FF2EA52B-9B32-4169-99A7-2C9E5FD7063B

\title{
Review of the genus Cystocnemis (Coleoptera: Chrysomelidae: Chrysomelinae) with descriptions of two new species
}

\author{
YURI E. MIKHAILOV' ${ }^{1} \&$ ELENA V. GUS'KOVA ${ }^{2}$ \\ ${ }^{1}$ Ural Federal University, Yekaterinburg, 620083, Russia and Ural State Forest Engineering University, Yekaterinburg, 620100, Rus- \\ sia.E-mail: yuemikhailov@gmail.com \\ ${ }^{2}$ Altai State Agrarian University, Barnaul, 656049, Russia.E-mail: guskovael@mail.ru
}

\begin{abstract}
Two new species of Cystocnemis (s. str.) Motschulsky, 1860 namely C. levmedvedevi sp. nov. and C. zintshenkoi sp. nov. are described from the Mongolian Altai (Mongolia, Hovd aimag) and Southern Altai (Kazakhstan, East-Kazakhstan region) respectively. Generic diagnosis as well as key to species and subspecies of Cystocnemis are provided. Zoogeographical affinities of Entomoscelini are discussed.
\end{abstract}

Key words: Chrysomelidae, Cystocnemis, Entomomela, new species, Mongolian Altai, Southern Altai, Dzhungaria

\section{Introduction}

The chrysomeline tribe Entomoscelini (sensu Kippenberg 2010) contains 12 genera, out of which Entomoscelis Chevrolat, 1836, Cystocnemis Motschulsky, 1860, Xenomela Weise, 1884 and Oreomela Jacobson, 1895, were considered as sister groups by Lopatin (1989) and are closely related. Potaninia Weise, 1889, Suinzona Chen, 1931 and Taipinus Lopatin, 2007 form another generic cluster (Ge et al. 2011) related to the previous group. However, elucidating precise relationships require further phylogenetic analysis within the Entomoscelini which is not addressed here.

Among the above genera, Entomoscelis has the widest Holarctic distribution, with just one species, E. americana Brown, 1942, occurring in the Nearctic Region. Occurrence of the remaining 12 species of Entomoscelis, including the newly described ones from China (Ge et al. 2009), and the residual genera, such as Cystocnemis, are limited to the Palaearctic Region. Within the Palaearctic, they are concentrated in the Central Asiatic Subregion of the Sahara-Gobian Desert Region and the Scythian Steppe Region (biogeographic subdivisions of Krivokhatsky \& Emeljanov 2000).

Oreomela is the most speciose genus of Entomoscelini with over 80 species. It is distributed through out the high mountains of Central Asia, with the centre of diversity in Tien-Shan (Lopatin \& Nesterova 2004) having the mountains of South Siberia as its northern limit (Mikhailov 2007). Cystocnemis and Xenomela occupy an intermediate position between the unspecialized Entomoscelis and the highly specialized Oreomela (Jacobson 1926; Lopatin 1989). Xenomela comprising 11 species, the subject of recent revisions (Lopatin 1989, 2010), is distributed only in Tien-Shan.

Cystocnemis has remained unrevised so far and the same three species that Jacobson (1926) attributed to this genus are included in the new Catalogue of Palaearctic Coleoptera (Kippenberg 2010). However, only two of the three described species are sufficiently well defined to be included here as the position of Cystocnemis koslovi Jacobson, 1926 is still unclear. This species is known only from a pair of specimens collected in 1908 by the Mongolian-Sichuanian expedition of Petr Kozlov from the Alashan Mountains in China. Moreover, black color with metallic tinge, as is the case in C. koslovi (Jacobson 1926), is atypical for the genus Cystocnemis. Lack of other known conspecific or at least congeneric representative in this region prevents us from treating this species here, which is also not included in the key. 


\section{References}

Dubeshko, L.N. \& Medvedev, L.N. (1989) Ekologiya listoedov Sibiri i Dalnego Vostoka [Ecology of Leaf Beetles of Siberia and Far East]. Irkutsk University Publ., Irkutsk, 224 pp. [in Russian]

Ge, S.-Q., Daccordi, M., Wang, S.-Y. \& Yang, X.-K. (2009) Study of the genus Entomoscelis Chevrolat (Coleoptera: Chrysomelidae: Chrysomelinae) from China. Proceedings of the Entomological Society of Washington, 111, 410-425. http://dx.doi.org/10.4289/0013-8797-111.2.410

Ge, S.-Q., Daccordi, M., Beutel, R.G., Li, W.-Z. \& Yang, X.-K. (2011) Revision of the chrysomeline genera Potaninia, Suinzona and Taipinus (Coleoptera) from eastern Asia, with a biogeographic scenario for the Hengduan mountain region in south-western China. Systematic Entomology, 36, 644-671. http://dx.doi.org/10.1111/j.1365-3113.2011.00581.x

Jacobson, G. (1895) Corrigenda. Horae Societatis Entomologicae Rossicae, 29, 294-297.

Jacobson, G. (1926) Chrysomelidae (Coleoptera) palaearctici novi vel parum cogniti. V-VI. Ezhegodnik Zoologicheskogo Muzeya AN SSSR, 26, 231-276.

Kamelin, R.V., Kutsev, M.G., Tikhonov, D.V., Shaulo, D.N., Shmakov, A.I. \& Viane, R.L.L. (2005) Flora Altaica. Vol. 1. Lycopodiophyta, Equisetophyta, Polypodiophyta. Azbuka Publ., Barnaul, 340 pp. [in Russian with English summary]

Kippenberg, H. (2010) Chrysomelinae. In: Löbl, I. \& Smetana, A. (Eds.), Catalogue of Palaearctic Coleoptera. Vol. 6. Chrysomeloidea. Apollo Books, Stenstrup, 390-443.

Krivokhatsky, V.A. \& Emeljanov, A.F. (2000) Usage of the general biogeographic subdivisions for particular zoogeographic researches exemplified by the Palaearctic fauna of antlions (Neuroptera, Myrmeleontidae). Entomologicheskoe Obozrenie, 79, 557-578. [in Russian with English summary]

Lopatin, I.K. (1977) Zhuki-listoedy (Chrysomelidae) Srednei Azii i Kazakhstana. [Leaf Beetles (Chrysomelidae) of Middle Asia and Kazakhstan]. Nauka Publ., Leningrad, 270 pp. [in Russian]

Lopatin, I.K. (1989) Genus Xenomela Weise (Coleoptera, Chrysomelidae) and its place in the tribus Entomoscelini. Trudy Zoologicheskogo instituta AN SSSR, 208, 110-124. [in Russian]

Lopatin, I.K. (2010) Zhuki-listoedy (Insecta, Coleoptera, Chrysomelidae) Central'noi Azii [Leaf Beetles (Insecta, Coleoptera, Chrysomelidae) of Central Asia]. Byelorussian University Publ., Minsk, 511 pp. [in Russian]

Lopatin, I.K. \& Kulenova, K.Z. (1986) Zhuki-listoedy (Chrysomelidae) Kazakhstana: Opredelitel' [Leaf Beetles (Chrysomelidae) of Kazakhstan: Identification keys]. Nauka Publ., Alma-Ata, 200 pp. [in Russian]

Lopatin, I.K. \& Nesterova, O. (2004) Biology and ecology of the mountainous genera Oreomela Jacobson, Xenomela Weise and Crosita Motschulsky (Coleoptera, Chrysomelidae, Chrysomelinae). In: New Developments in the Biology of Chrysomelidae. SPB Acad. Publ., The Hague, 415-421.

Medvedev, L.N. (1982) Listoedy MNR: Opredelitel' [Chrysomelidae of MNR: Identification keys]. Nauka Publ., Moscow, 340 pp. [in Russian]

Medvedev, L.N. \& Voronova, N.V. (1977) On the leaf beetles (Coleoptera, Chrysomelidae) fauna of Mongolia. 2. Nasekomye Mongolii, 5, 319-372. [in Russian]

Mikhailov, Yu.E. (2007) On the northernmost distribution of leaf beetles of the genus Oreomela (Coleoptera, Chrysomelidae): New species from mountains of southern Siberia. Entomological Review, 87, 740-749.

http://dx.doi.org/10.1134/s0013873807060097

Mikhailov, Yu.E. (2013) To knowledge of leaf-beetles of the genus Cystocnemis (Coleoptera, Chrysomelidae). Zoologicheskiy Zhurnal, 92, 300-312. [in Russian with English summary] http://dx.doi.org/10.7868/S0044513412120082

Mikhailov, Yu.E. \& Dudko, R.Yu. (2010) New for the Russian fauna and little known leaf beetles (Coleoptera, Chrysomelidae) from south-eastern Altai. Euroasian Entomological Journal, 9, 477-484. [in Russian with English summary]

Motschulsky, V. (1860) Coléoptères de la Sibérie orientale et en particulier des rives de l'Amour. In: Dr. L. von Schrenck's Reisen und Forschungen im Amur-lande. II, 2. Eggers \& Comp., St. Petersburg, pp. 80-57.

Novozhenov, Yu.I. \& Mikhailov, Yu.E. (1997) Fenetica perifericheskikh populaytsiy nekotoryh nasekomyh [Phenetics of peripheric populations of some insects]. In: Yablokov, A.V. (Ed.), Populyatsionnaya fenetica [Population Phenetics]. Nauka Publ., Moscow, pp. 89-100. [in Russian]

Warchałowski, A. (2010) The Palaearctic Chrysomelidae. Identification keys. Vol. 1. Natura optima dux Foundation, Warszawa, $629 \mathrm{pp}$.

Yakovlev, R.V. (2012a) Butterflies (Lepidoptera: Papilionoidea) of Arshantyn-Nuruu Mountains Range (Western Mongolia). Amurian Zoological Journal, 4, 54-60. [in Russian with English summary]

Yakovlev, R.V. (2012b) Checklist of Butterflies (Papilionoidea) of the Mongolian Altai Mountains, including descriptions of new taxa. Nota Lepidopterologica, 35, 51-96. 